\title{
DAMPAK GARAR TERHADAP KEABSAHAN \\ AKAD MUAMALAH KONTEMPORER
}

\author{
THE IMPACT OF GARAR ON THE VALIDITY \\ OF THE CONTEMPORAR MUAMALAH CONTRACT
}

\begin{abstract}
Enang Hidayat ${ }^{1}$
1Jurusan Ekonomi Syariah Program Pascasarjana, Fakultas Ekonomi dan Bisnis Islam, Jl. William Iskandar Ps. V, Medan Estate, Kec. Percut Sei Tuan, Kabupaten Deli Serdang, Sumatera Utara 20371 Universitas Islam Negeri Sumatera Utara l. Perintis Kemerdekaan No.99, Sayang, Kec. Cilaku, Kabupaten Cianjur, Jawa Barat 43213

E-mail: enanghidayat17@gmail.com ${ }^{1}$
\end{abstract}

\begin{abstract}
This study aims to determine the impact of garar on the validity of the contract and to analyze some potential of garar in contemporary agreement. The research employs descriptive qualitative. The technique is to determine types of garar according Hanafiah, Malikiah, Syafiiah, and Hanabilah and then analyze the impact of it to the validity of contract including contemporary ones. This research concludes there are three type of garar and kasir is the most important one. Kasir most likely inflicts one of the parties and potentially causes conflict in the future. Therefore, kasir garar makes the contract defective (fasad). According to Hanafiah scholars, the defective contract remains valid. Meanwhile, according to the majority of scholars (Malikiah, Syafiiah, and Hanabilah) because there is no difference between a defective and a canceled contract, the defective contract law is invalid. This research also shows that there are some potential of garar in online trading and insurance agreement.
\end{abstract}

Key words: garar, fasad, Invalid, jahalah, khilabah, tadlis, gasyi, gaban.

\begin{abstract}
ABSTRAK
Penelitian jni bertujuan mengidentifikasi pengaruh garar terhadap keabsahan akad dan menganalisis beberapa potensi garar dalam akad jual beli kontemporer. Penelitian ini menggunakan pendekatan kualitatif. Metode analisis yang digunakan adalah deskriptif kualitatif yang menganalisis jenis garar berdasarkan pendapat ulama Hanafiah, Malikiah, Syafiiah, dan Hanabilah lalu mendiskusikan pengaruhnya terhadap kesahihan akad termasuk di dalamnya akad kontemporer. Penelitian ini berkesimpulan bahwa ada tiga jenis garar dan garar kasir adalah yang paling utama, karena bisa merugikan salah seorang dan sangat berpotensi menimbulkan konflik di masa depan. Oleh karena itu garar kasir sangat memungkinkan menyebabkan kerusakan akad. Berdasarkan pendapat ulama Hanafiah, akad yang rusak masih dianggap sah. Sementara itu berdasarkan jumhur ulama, karena tidak ada perbedaan yang pasti antara akad yang rusak dan yang ditangguhkan, maka akad yang rusak dikategorikan tidak sah. Penelitian ini pula menunjukkan bahwa ada potensi garar dalam akad jual beli online dan asuransi
\end{abstract}

Kata kunci: Garar, fasad, batal, jahalah, khilabah, tadlis, gasyi, gaban. 
Enang Hidayat. 2020. Dampak Garar Terhadap Keabsahan Akad Muamalah Kontemporer. Jurnal Syarikah 6(2): $114-122$.

\section{PENDAHULUAN}

Masalah garar merupakan hal yang menarik untuk diperbincangkan dalam akad muamalah maaliah. Imam Nawawi menegaskan karena garar termasuk persoalan yang agung dan memerlukan perhatian khusus untuk memecahkannya. Terutama sangat dominan dalam persoalan akad jual beli.

Kendatipun masalah garar ini mayoritas berkaitan dengan praktik zaman Jahiliah dahulu kala. Namun tak menutup kemungkinan zaman sekarang pun bermunculan. Justru persoalan muamalah kontemporer pun embrionya berasal dari persoalan muamalah zaman dahulu kala.

Sekalipun bahaya yang ditimbulkan oleh garar lebih sedikit daripada bahaya karena riba sebagaimana yang ditegaskan Ibnu Taimiah. Namun tak menutup kemungkinan bahayanya akan sebanding. Hal ini jika praktik garar sudah merajela di masyarakat, seperti riba. Apalagi jika berangkat dari pemikiran baik garar maupun riba merupakan kebiasaan zaman Jahiliah dahulu. Bedanya jika dalam garar ada yang diperbolehkan. Sedangkan dalam riba tidak ada yang diperbolehkan. Barangkali inilah yang menyebabkan bahaya riba lebih besar daripada garar.

Garar ini dapat berpotensi mengandung perselisihan di kemudian hari di antara kedua belah pihak yang terlibat dalam akad. Namun dalam praktiknya selain istilah garar, ternyata terdapat pula istilah lainnya yang berpotensi sama, seperti jahalah, tadlis, gasyi, dan khilabah.

Tujuan penelitian ini akan menjawab dampak garar terhadap keabsahan akad menurut para ulama dan akad-akad muamalah kontemporer yang berpotensi mengandung garar di dalamnya serta dampak keabsahannya.

\section{MATERI DAN METODE}

Penelitian ini berisi materi permasalahan garar dan istilah-istilah lainnya yang semisalnya berikut persamaan dan perbedaannya. Kemudian dampak garar bagi kebasahan akad. Selanjutnya penelaahan terhadap akad kontemporer yang berpotensi mengandung garar serta dampak kebsahannya. Oleh karena itu metode penelitian ini adalah menggunakan metode penelitian kualitatif. Adapun teknik analisisnya menggunakan deskriptif kualitatif yang menganalisis garar dan macam-macamnya serta istilah-istilah lainnya yang semisalnya. Kemudian menganalisis dampak garar terhadap keabsahan akad menurut para ulama. Selanjutnya menganalisis pendapat para ulama mengenai akad-akad kontemporer yang berpotensi mengandung garar di dalamnya serta dampak keabsahannya.

\section{HASIL DAN PEMBAHASAN}

\section{Pengertian Garar}

Secara bahasa kata "al-garar" (ال غرر) menurut Al-Fairuzabadi, Ibnu Manzur, AlZubaidi, dan Luis Makluf semakna dengan kata "al-khad'u" (ال خذع) yang berarti tipudaya. Sementara itu Al-Fayumi dan AlJauhari menyebutnya dengan "al-Khatr" (ال خطر) yang berarti bahaya. Sedangkan pengertian garar menurut istilah menurut para ulama sebagaimana dikutif Yasin Ahmad Ibrahim berikut ini.

Hanafiah mendefinisikan garar dengan sesuatu yang tersembunyi akibatnya, dan tidak dapat diketahui ada atau tidaknya درى لا الـ عاق بة مجهول ماي كون (ر) ال أم أي كون Malikiah mendefinisikan garar dengan sesuatu yang ragu antara selamat (terbebas dari cacat) dan rusaknya barang (وال عطب السّلامة بـ ين تردّد مال.). Syafiiah mendefinisikan garar dengan sesuatu yang tersembunyi akibatnya (عاق بـ ته مااذطوت). Hanabilah mendefinisikan garar 
dengan sesuatu yang ragu antara dua hal. Dan salah satu dari keduanya tidak jelas (أظهر أحدهال يس أمري ن ب ين (تردّد

Sementara itu, Al-Mausuah alFiqhiyah mendefinisikan garar dengan ketidakjelasan sesuatu yang berhubungan dengan akad yang dilakukan manusia seperti jual beli, sewa-menyewa, pinjam-

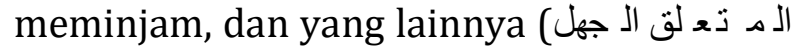

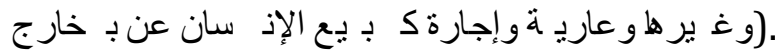

Dari beberapa definisi garar baik menurut bahasa maupun menurut istilah dapatlah ditarik suatu kesimpulan bahwa garar adalah ketidakjelasan mengenai kualitas atau kuantitas atau penyerahan objek akad, seperti barang yang akan diperjualbelikan, disewakan, atau yang lainnya. Dan dampak hukum yang diakibatkan karenanya tidak jelas pula. Sehingga berpotensi dapat merugikan orang lain secara finansial.

\section{Macam-macam Garar}

Para ulama

sebagaimana

dikemukakan Syekh Izzudin bin Abdul Salam membagi garar ini kepada tiga macam. Pertama, garar yang sulit dihindarkannya menurut kebiasaan. Garar ini dikenal pula dengan al-garar al-yasir, yakni garar yang ringan dan tidak berpotensi menimbulkan perselisihan di kemudian hari antara kedua belah pihak. Keberadaannya dimaafkan syara' karena tidak merusak akad. Oleh karena itu para ulama membolehkan garar jenis ini karena alasan kebutuhan (hajat). Contoh garar jenis ini seperti jual beli kacang tanah, buah delima, dan buah semangka. Selain itu seperti jual beli rumah tanpa terlihat keadaan pondasinya dan jual beli jas tanpa melihat dahulu keadaan busa yang ada di dalamnya.

Kedua, garar yang tidak sulit menghindarkannya. Garar ini dikenal pula dengan al-garar al-fahisy, yakni garar yang berat dan berpotensi menimbulkan perselisihan di kemudian hari antara kedua belah pihak. Dan keberadaannya tidak dimaafkan syarak karena merusak akad sehingga menyebabkan akad batal. Oleh karena itu, para ulama tidak membolehkan garar jenis ini. Contoh garar jenis ini seperti jual beli burung yang sedang terbang di udara, jual beli ikan yang ada di kolam, dan yang lainnya.

Ketiga, garar yang posinya berada di antara dua garar sebelumnya (mutawassit). Para ulama pun memperselisihkan keberadaan hukumnya. Artinya berkaitan apakah garar tersebut hukumnya diperbolehkan atau tidak. Di antara para ulama ada yang menghubungkannya jika potensi garar-nya terkadang menjadi besar, seperti seperti jual beli kelapa yang masih hijau kulitnya. Garar seperti ini tidak dimaafkan. Karena termasuk garar kasir. Dan ada juga yang menghubungkannya jika potensi garar-nya terkadang menjadi ringan, seperti seperti jual beli sayuran yang masih hijau kulitnya. Garar seperti ini dimaafkan. karena termasuk garar yasir.

$$
\text { Selanjutnya Imam Nawawi }
$$

menyebutkan perdebatan para ulama seputar jenis garar ini seperti dalam kasus jual beli gandum yang masih dalam tangkainya. Sebagian para ulama berpandangan hal tersebut ke dalam garar yasir yang hukumnya diperbolehkan. Sedangkan sebagiannya berpandangan garar yasir, tapi hukumnya tidak diperbolehkan.

Sulit untuk mengetahui jenis garar ketiga ini yang keberadaannya di antara dua jenis garar. Oleh karena itu agar mudah mengetahuinya, lebih tepat jika garar ini dibagi menjadi dua macam, yakni garar yasir dan garar kasir. Indikasinya jika garar itu sulit untuk dihindarkannya, maka termasuk garar yasir yang diperbolehkan. Sebaliknya, jika garar itu mudah untuk dihindarkannya, maka termasuk garar kasir yang tidak diperbolehkan.

Persamaan dan Perbedaan antara Garar, Jahalah, Tadlis, Gasyi, Gaban, dan Khilabah

Terdapat kata yang serupa dengan kata garar, yakni jahalah, tadlis, gasyi, dan khilabah. Dan para ulama pun membedakannya di antara kata-kata tersebut. Sebelum membahas persamaan dan perbedannya, perlu di sini dijelaskan 
definisinya, selain kata garar sebagai berikut.

\section{Jahalah}

Kata jahalah جهالة) secara bahasa berarti tidak mengetahui. Para ulama seperti Ibnu Manzur, Al-Fairuzabadi, AlJauhari, Al-Zubaidi, dan Ibnu Faris sepakat kata jahalah kebalikan atau berlawanan خلاف أو ضد أو ذن قيض) dengan kata ilmu (ال ع لم), yang berarti mengetahui atau dalam bahasa Rawas Qalahji dan Hamid Sadiq Qanibi pengertian tersebut disebut dengan adamul ma'rifat (المعرف menambahkan pengertiannya adalah engkau melakukan sebuah perbuatan tanpa

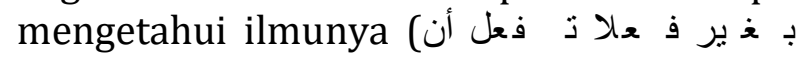

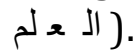

Sedangkan kata jahalah menurut istilah disebutkan dalam Al-Mausuah alFiqhiyah penggunaannya dalam dua hal. Pertama, kata tersebut maksudnya berkaitan dengan keadaan yang ada dalam diri manusia, baik berupa keyakinan (iktikad), ucapan atau perbuatan. Kedua, kata tersebut maksudnya sesuatu yang samar berkaitan dengan perbuatan manusia, seperti akad jual beli, sewamenyewa, pinjam-meminjam, dan yang lainnya. Begitu pun berkaitan dengan rukun dan syaratnya. Dan makna kedua inilah yang dimaksud jahalah hubungannya dengan persoalan akad muamalah maaliah. Sedangkan makna pertama maksudnya jahl menurut bahasa sebagaimana telah disebutkan di atas.

Dari definisi tentang jahalah ini baik dari segi bahasa maupun istilah dapat kita simpulkan pengertiannya adalah sesuatu yang samar atau ketidakjelasan yang berkaitan dengan persoalan muamalah maaliah seperti akad jual beli, sewamenyewa, dan yang lainnya. Ketidakjelasan di sini biasanya berkaitan dengan objek, termasuk rukun dan syaratnya. Dampaknya menyebabkan akad tersebut tidak sah.

\section{Tadlis}

Kata tadlis (ت دل يس) menurut bahasa berarti gelap (الـ المة). Sedangkan menurut istilah adalah jika dikaitkan dengan akad jual beli adalah seorang penjual menyembunyikan cacat pada barang yang akan dijual kepada pembeli. Demikian dikemukakan Ibnu Manzur.

Lebih lengkap lagi Ibnu Faris menjelaskan kata tadlis menurut bahasa berarti sumber yang menunjukkan sesuatu yang menutupi dan kegelapan. Dengan demikian tadlis dalam jual beli maksudnya seorang penjual yang berprilaku demikian sebagaimana yang telah didefinisikan Ibnu Manzur tersebut seolah-olah ia telah menipu si pembeli dan telah menzaliminya.

Sementara itu Rawas Qal'ahji dan Hamid Sadiq Qanibi menjelaskan pula kata tadlis menurut bahasa menyamarkan sesuatu. Sedangkan menurut istilahnya sama seperti apa yang dikemukakan Ibnu Faris dan Ibnu Manzur di atas.

Dari definisi tentang tadlis tersebut para ulama nampaknya sepakat ketika dikaitkan dengan jual beli yang intinya tindakan tadlis ini berpotensi dapat merugikan pembeli secara finansial. Oleh karena itu dapat ditarik kesimpulan tindakan tadlis ini dapat merusakan akad.

\section{Gasyi}

Kata gasyi (غش) menurut Ibnu Manzur

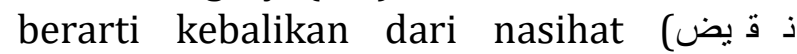
(ال ذصح yang diambil dari kata gasyasyun (غ شش) yang berarti tempat air minum yang keruh (ال كدر الـشرب). Sementara itu Rawas Qalahji dan Hamid Sadiq Qanibi mengartikan kata gasyi dengan kata tipu daya (خداع). Sedangkan menurut istilah mengandung tiga pengertian. Pertama, menampakkan sesuatu yang bukan sebenarnya. Kedua, mencampur sesuatu yang dapat mengurangi harganya. Ketiga, keluar dari niat yang baik dalam bermuamalah.

Dari beberapa pengertian tentang gasyi di atas dapat ditarik suatu kesimpulan bahwa kata gasyi berkonotasi negatif, yakni suatu tindakan ketidakterus-terangan terkait dengan barang yang diperjualbelikan. Sehingga berpotensi menimbulkan kerugian bagi pihak pembeli.

\section{Gaban}

Kata gaban (غ بن) menurut Ibnu Manzur berarti kerugian (وكس). Ibnu Faris 
menambahkan kata gaban berarti sebuah kalimat yang menunjukkan kepada kekurangan dan kerugian. Sedangkan kata gaban menurut istilah, Al-Hatab mengartikannya dengan sebuah ungkapan tentang menjual barang dagangan dengan harga yang lebih mahal dari keumumannya.

Dari beberapa pengertian tentang gaban di atas dapat ditarik suatu kesimpulan bahwa kata gaban berarti tindakan yang dapat merugikan pihak pembeli. Namun Al-Hitab menambahkan kerugian di sini maksudnya tentang harga yang terlalu mahal menurut kebiasaan ketika menjual barang. Sehingga karenanya pihak pembali merasa tertipu.

\section{Khilabah}

Kata khilabah menurut Ibnu Manzur berarti tipu daya (خداعة). Sama halnya dengan Ibnu Manzur, Ibnu Faris mengartikan kata khilabah dengan tipu daya ( $k h i d a^{\prime}$ ). Sementara itu Rawas Qal'ahji dan Hamid Sadiq Qanibi mengartikannya dengan memiringkan hati dengan cara membaguskan ucapan.

Dari beberapa pengertian tentang khilabah di atas dapat ditarik suatu kesimpulan bahwa kata khilabah berarti tindakan tipu daya penjual terhadap pembeli mengenai barang yang diperjualbelikan, seperti dengan mengatakan barang itu bagus kualitasnya, sehingga si pembeli tertarik untuk membelinya, padahal sebaliknya.

Jika kita memahami dengan cermat antara istilah garar, jahalah, tadlis, gasyi, gaban, dan khilabah memiliki persamaan terkait konotasinya negatif, yakni potensi kerugian yang diakibatkan perbuatan penjual untuk mengelabui pembeli. Namun perbedaannya terletak hanya pengungkapannya dalam hadis, yakni kata garar, gasyi, dan khilabah yang ditegaskan Rasulullah. Kata garar terdapat dalam hadis: ال غرر بـ يع عن اللهر سول ذهى . Kemudian kata غش من مدنال يس:وasyi teradapat dalam hadis. Selanjutnya kata khilabah terdapat dalam خلاب ة لا ف قل بـ ايد عت إذا.

Selain itu perbedaannya bisa dilihat dari segi pengertiannya. Kata gasyi lebih umum dari yang lainnya. Hal ini sebagaimana yang telah dikemukakan Rawas Qalahji dan Hamid Sadiq Qanibi di atas mengandung tiga pengertian. Artinya makna gasyi ini secara implisit mencakup garar, jahalah, tadlis, gaban, dan khilabah. Hal ini terjadi bisa dengan ucapan dan perbuatan yang tujuannya mengelabui pembeli terkait barang yang dijual. Sehingga ia mengalami kerugian secara finansial. Di dalamnya terkait juga dengan keadaan barang atau harganya. Namun demikian yang lebih populer adalah kata garar,jika dikaitkan dengan akad jual beli, sehingga dinamakan baiul garar.

\section{Dampak Garar atau Jahalah terhadap Akad yang telah Dilakukan}

Sebagaimana telah dikemukakan mengenai pembagian garar, maka garar yang dapat merusak akad adalah garar dalam kategori kasir atau fahisy. Inilah yang dilarang dalam hadis Rasulullah. Alasan larangan tersebut karena berpotensi dapat menimbulkan kerugian kepada salah satu pihak secara finansial.

Akad yang rusak (fasad) didefinisikan oleh ulama Hanafiah seabagai akad yang cacat karena karena menyalahi aturan syarak. Sehingga menyebabkan salah satu pihak ada hak membatalkan akad (fasakh).

Mustafa Al-Zarqa menjelaskan makna tentang fasad (rusak) dalam akad tersebut kepada tiga hal. Pertama, hakikat fasad adalah cacatnya sebuah akad, karena berlawanan dengan aturan syarak. Kedua, pengaruh fasad dapat menyebabkan salah satu pihak mempunyai hak membatalkan akad. Ketiga, akad fasad hukumnya tergolong akad yang sah, karena dilihat dari segi sifat akad tersebut, yakni salah satu pihak punya hak membatalkan akad.

Dari pengertian tentang akad rusak di atas dapat ditarik suatu kesimpulan bahwa istilah batal lebih umum daripada fasad. Karena itu para ulama seperti ulama Hanafiah sebagaimana dikemukakan Ibnu Abidin akad fasad adalah akad yang disyariatkan asalnya, tapi sifatnya tidak. Sedangkan akad batal adalah akad yang 
tidak disyariatkan baik asalnya maupun sifatnya. Contoh disyariatkan asalnya (dalam akad fasad) seperti barang yang diperjualbelikan itu dipandang harta oleh syarak. Namun karena dalam akadnya terdapat cacat seperti adanya garar, maka jadilah rusak akad tersebut. Berbeda jika akad itu dipandang batal, karena memang asalnya tidak boleh diperjualbelikan seperti khamar atau minuman keras .

Berbeda dengan pandangan ulama Hanafiah, mayoritas ulama sebagaimana dijelaskan dalam Al-Mausuah al-Fiqhiah tidak membedakan antara fasad dan batal. Keduanya menunjukkan suatu perbuatan yang berlawanan dengan syarak. Oleh karena itu suatu akad yang mengandung keduanya sia-sia, tidak seperti akad sahih. Dengan demikian kebalikan dari akad fasad dan batal adalah akad sahih.

Akibat tidak ada perbedaan di antara keduanya, mayoritas ulama berpandangan sebab-sebab yang dapat merusak akad disebut juga sebab-sebab yang dapat membatalkan akad. Misalnya karena tidak terpenuhinya rukun dan syarat dalam jual beli, dan yang lainnya.

Dengan memahami pengertian tentang akad garar itu kenapa dilarang Rasulullah, bagi ulama Hanafiah penafsirannya, karena mengandung fasad. Dan itu pun garar yang termasuk kategori kasir atau fahisy. Garar atau jahalah merupakan penyebab umum yang dapat merusak akad. Namun sebagaimana telah dikemukakan di atas garar atau jahalah kasir atau fahisy. Kendatipun demikian para ulama ada yang membedakan antara istilah garar dengan jahalah. Al-Qurafi salah satu ulama Malikiah mengatakan garar adalah sesuatu yang belum bisa diketahui apakah sesuatu itu bisa diperoleh atau tidak, seperti burung yang ada di udara, dan ikan yang ada di kolam.

Sedangkan jahalah adalah sesuatu itu bisa diperoleh, tetapi tidak diketahui jenis, bentuk, dan sifatnya. Misalnya jual beli yang dilakukan oleh orang yang buta. Dia bisa memperoleh barang tersebut, namun tidak tahu bagaimana kondisi barang tersebut.
Contoh lainnya seperti seseorang yang mempekerjakan orang lain tanpa memberitahukan secara jelas mengenai upahnya. Atau dua orang yang melakukan bisnis, tanpa menjelaskan bagian masingmasing dari keuntungannya. Semua itu dapat merusak akad.

Berbeda kasusnya jika seseorang menjual sesuatu yang tidak berpotensi dapat menimbulkan pertentangan di kemudian hari. Contohnya seseorang menjual setiap benda miliknya yang ada di dalam rumahnya, tanpa menyebutkannya secara rinci. Jual beli demikian hukumnya sah, sekalipun samar (jahalah). Sedangkan sebagian ulama lainnya misalnya Ibnu Taimiah mengemukakan bahwa garar lebih umum daripada jahalah. Dengan kata lain jahalah merupakan bagian dari garar.

Menurut sebagian ulama dalam prakteknya membedakan antara garar dan jahalah merupakan hal yang sulit. Hal ini berbeda dengan Al-Qurafi yang berusaha membedakannya. Walaupun beliau sendiri dalam mengklasifikasikan keduanya kepada tiga macam berusaha tidak memisahkannya sebagaimana telah disebutkan di atas dalam penjelasan macam-macam garar.

Terlepas dari perbedaan pendapat ulama mengenai garar dan jahalah, yang jelas terdapat titik persamaan antara keduanya, yakni sama-sama dapat merusak akad apabila keduanya (garar dan jahalah) yang berpotensi menimbulkan pertentangan di kemudian hari. Atau lebih sederhananya garar atau jahalah yang kasir atau fahisy. Dengan demikian makna hadis yang melarang garar, karena dapat merusak akad sebagaimana telah disinggung di atas maksudnya secara implisit termasuk juga jahalah di dalamnya yang sifatnya demikian (kasir atau fahisy).

\section{Akad Kontemporer yang Berpotensi Mengandung Garar dan Dampak Keabsahannya}

Imam Nawawi pernah mengatakan larangan jual beli yang mengandung garar merupakan pokok permasalahan yang agung dalam pembahasan jual beli. Karena di dalamnya terdapat permasalahan yang 
banyak diperbincangkan para ulama. Termasuk di dalamnya baik yang berkaitan dengan garar yang kasir atau fahisy yang dapat merusak akad atau yang diperbolehkan karena alasan kebutuhan. Contohnya telah dikemukakan pula dalam pembahasan pembagian garar di atas.

Imam Nawawi juga menambahkan terdapat garar yang diperbolehkan dengan sebutan garar haqir, yakni garar yang dipandang rendah. Maksud Imam Nawawi mungkin garar demikian karena tidak berpotensi menimbulkan pertentangan di kemudian hari. Contohnya diperbolehkan menyewakan mobil atau rumah selama sebulan. Hal demikian berpotensi garar, karena tanpa ada penjelasan berapa lamanya waktu sebulan dimaksud. Karena dalam praktiknya sebulan itu waktunya terkadang selama tiga puluh hari atau dua puluh sembilan hari. Contoh lain diperbolehkan memberi tarif misalnya Rp. 2000 jadi depan wc jika ingin masuk ke dalamnya. Hal demikian berpotensi garar juga, karena orang yang masuk wc tersebut berbeda kebutuhannya. Di antara mereka ada yang buang air kecil atau buang air besar. Lagi pula kadar mungkin pemakaian air di dalamnya berbeda.

Dari beberapa contoh tentang garar di atas bisa dipahami kenapa Imam Nawawi mengatakan permasalahan garar merupakan permasalahan agung dalam pembahasan jual beli. Selain alasan di atas, karena jika kita tidak cermat memahami garar tersebut, maka berpotensi keliru dalam memahaminya. Sehingga mungkin saja kita berpendapat garar itu semuanya dilarang. Padahal tidak demikian. Karena kenyataannya ada garar yang diperbolehkan. Itulah sebabnya penting sekali kita memahami permasalahan garar ini, terutama jika dihubungkan dengan permasalahan muamalah kontemporer.

Di antara akad kontemporer yang berpotensi mengandung garar adalah sebagai berikut.

\section{Jual beli online}

Jual beli online banyak dilakukan oleh masyarakat pada zaman sekarang.
Sepanjang terpenuhi rukun dan syaratnya, maka akad tersebut dipandang sah. Rukunnya seperti ada penjual dan pembeli, ada barang yang diperjualbelikan, dan ijab kabul. Sedangkan syaratnya seperti barang yang diperjualbelikan dipandang harta menurut agama Islam. Akan tetapi jual beli ini berpotensi garar jika barang yang ditunjukkan dalam media online tidak sesuai dengan kenyataannya, seperti kualitasnya. Hal ini dapat diketahui setelah barang sudah sampai di tempat pembeli, melalui paket pos, JNE, atau yang lainnya setelah pembeli mentransfer uang seharga barang. Dengan demikian jelas tindakan seperti ini termasuk ke dalam garar kasir ataau fahisy yang dapat merusak akad dan hukumnya dilarang. Karena mudah bagi penjual untuk menghindarkan agar tidak terjadi potensi garar tersebut.

Di satu sisi jual beli online ini sebagai dampak kemajuan teknologi yang dapat mempermudah masyarakat untuk melaksanakan transaksi jarak jauh. Namun di sisi lain terdapat potensi untuk mengelabui pembeli.

Apabila kita menerima perbedaan antara garar dan jahalah sebagaimana dikemukakan Al-Qurafi di atas, karena barang yang diperjualbelikan tidak diketahui secara pasti, baik jenis, bentuk, maupun sifatnya, namun dalam praktik jual beli online barang yang diperjualbelikan dapat diketahui melalui layar komputer melalui jaringan internet. Kendatipun demikian, si penjual berpotensi antara jujur dan mengelabui pembeli berkaitan dengan kondisi barang, baik kualitas maupun sifatnya.

\section{Asuransi}

Akad asuransi dalam bahasa Arab disebut dengan al-Ta'min (ال تأم ين). Masalah hukum asuransi ini termasuk masalah ijtihadiah. Oleh karena itu mengandung pemahaman yang berbeda, yakni ada ulama yang membolehkan dan ada pula yang mengharamkannya. Dalam hal ini termasuk ulama kontemporer. Ulama yang membolehkan di antara alasannya sebagai berikut: 1) merupakan jalan 
antisipasi atau kehati-hatian terhadap peristiwa mudarat yang akan terjadi di masa yang akan datang. Karenanya dengan adanya asuransi, hal tersebut bisa diatasinya; 2) dapat mendorong hati tenang; 3) termasuk akad mudarabah; 4) mengandung kemaslahatan dengan adanya saling membantu. Pendapat demikian dikemukakan oleh Syekh Ali al-Khafif, Syekh Abdul Wahhab Khalaf, Dr. Muhammad alBahi, Syekh Abdul Munsif Mahmud, Dr. Muhamad Yusuf Musa. Dari keempat alasan kebolehannya jika dianalisis intinya tersimpul karena alasan kemaslahatan.

Sedangkan ulama

yang mengharamkannya beralasan sebagai berikut: 1) tidak mengandung akad daman, karena dalam akad daman itu berupa jaminan utang yang tetap. Sedangkan utang dalam asuransi tidak diketahui. Begitu pun tidak termasuk akad mudarabah, karena dalam akad mudarabah adanya perjanjian pembagian keuntungan; 2) asuransi termasuk akad fasid, karena ada unsur judi, yakni akad yang tergantung pada resiko yang terkadang terjadi dan terkadang tidak terjadi; 3) mengandung garar, karena berkaitan dengan akad yang mengandung kemungkinan peristiwa itu terjadi atau tidak. Pendapat demikian dikemukakan oleh Syekh Muhammad Bukhit al-Muti'i, Yusuf Qardawi, Syekh Abdul Rahman Qara'ah, Jalal Mustafa al-Sayad. Keterangan lebih lanjut berkenaan dengan hukum asuransi dapat dibaca dalam kitab berjudul "Al-Ta'min baina al-Hill wa al-Tahrim" karya Isa Abduh. Alasan terakhir inilah bagi ulama yang mengharamkan kenapa asuransi berpotensi mengandung garar. Para ulama yang berpendapat demikian tidak secara ekplisit menyatakan larangan tersebut tergolong ke dalam jenis garar yang mana. Namun jika dilihat dari kenyataan upaya menghindarkan agar tidak terjadi garar tersebut adalah mudah, maka jelas termasuk ke dalam garar kasir/fahisy.

Jual beli melalui online merupakan salah satu permasalahan muamalah maaliah kontemporer. Istilah lainnya dikenal juga dengan istilah perdagangan melalui elektronik. Penelitian melalui perdagangan ini sepengetahuan penulis pernah dilakukan oleh Sulaiman Abdul Raziq Abu Mustafa melalui Tesisnya dalam bidang Fikih Perbandingan (Fikih Muqaran) pada Fakultas Syariah Universitas Gaza yang berjudul "Al-Tijarah al-Iliktroniyah fi al-Fiqh al-Islami". Penelitian ini memberikan kesimpulan hukum asal persoalan muamalah termasuk muamalah kontemporer seperti perdagangan melalui elektronik (seperti telegraf, internet, email, dan yang lainnya) adalah diperbolehkan selama rukun dan syarat dalam akad tidak berlawanan dengan ketentuan dalam fikih Islam. Namun penelitian ini tidak membahas secara khusus mengenai analisis garar dalam akad tersebut serta dampaknya terhadap keabsahan akadnya. Begitu pun penelitian Adnan bin Jam'an al-Zahrani melalui Disertasinya dalam bidang Fikih Islam pada Fakultas Syariah Universitas Ummul Qura Mekkah Mukarramah berjudul "Ahkam al-Tijarah al-Iliktroniyah fi al-Fiqh al-Islam". Penelitian ini lebih luas lagi daripada penelitian Tesis Sulaiman Abdul Razaq di atas. Karena di dalamnya menyangkut juga bentuk muamalah kontemporer seperti yang terdapat dalam pasar modal dan disinggung juga asuransi bisnis (asuransi tijari). Di dalamnya dibahas analisis kaidah fikih yang berkaitan dengannya. Namun di dalamnya tidak disinggung pembahasan analisis garar berkenaan dengan muamalah tersebut.

Dengan demikian penelitian ini mengintegrasikan penelitian yang berkaitan dengan persoalan muamalah kontemporer jual beli online dan asuransi sebagaimana terungkap dalam penelitian sebelumnya tersebut. Namun pendekatan penulis dalam penelitian ini melalui analisis garar dari segi klasifikasinya. Sedangkan penelitian mengenai asuransi terutama asuransi jiwa penulis melakukan pendekatan analisis terhadap pendapat para ulama mengenai hukum asuransi sebagaimana yang terdapat dalam kitabkitab fatwa mengenai asuransi seperti kitab berjudul"Al-Ta'min baina al-Hill wa al- 
Tahrim" karya Isa Abduh dan kitab berjudul "Fatawa al-Ta'min" yang dikompilasikan oleh Abdul Sattar dan Izzudin Muhammad Khujah.

\section{KESIMPULAN DAN IMPLIKASI}

Dampak garar kasir atau fahisy menjadi kendala dalam akad muamalah, karena dapat merusak akad. Sedangkan garar yasir tidak menyebabkan rusaknya akad. Disebut merusak akad, karena menyalahi aturan syarak yang telah ditentukan. Dampak garar demikian berpengaruh terhadap hak seseorang untuk membatalkan akad. Akad yang fasad secara hukum tetap sah. Akan tetapi terdapat kecacatan dalam akad. Hal ini kesimpulan dari pemikiran ulama Hanafiah yang membedakan antara akad yang fasad dan akad yang batal. Pada hakikatnya menurut Hanafiah akad yang fasad disyariatkan asalnya, tapi sifatnya tidak. Sedangkan akad batal adalah akad yang tidak disyariatkan baik asalnya maupun sifatnya. Sedangkan menurut pandangan mayoritas ulama akad fasad hukumnya tidak sah, karena hakikatnya tidak ada perbedaan antara akad fasad dengan akad batal.

Garar berpotensi dalam akad kontemporer jual beli online dan akad asuransi. Namun agar tidak terjadi garar dalam akad jual beli online bisa diatasi asalkan terpenuhinya rukun dan syaratsyaratnya, seperti barang yang diperjualbelikan spesifikasi dan kualitasnya sesuai dengan kenyataan sebagaimana yang telah ditentukan syara'. Jika tidak terpenuhi keduanya, maka dampaknya menyebabkan akad rusak atau batal. Potensi garar kasir yang dimaksud dalam hal ini. Sedangkan untuk akad asuransi, karena termasuk masalah ijtihadiah, maka potensi garar di di sini diperdebatkan keberadaannya.

Penelitian ini berimplikasi bahwa permasalahan garar ini agar lebih dipertajam lagi kajiannya di perguruan tinggi keagamaan Islam yang menyelenggarkan program studi hukum ekonomi syariah atau ekonomi syariah baik berkenaan dengan penelaahan terhadap kaidah fikih yang berkaitan dengan garar maupun penelaahan terhadap akad kontemporer yang berpotensi garar di dalamnya.

\section{DAFTAR PUSTAKA}

Abdul Salam, Syekh Izzudin bin. t.th. AlQawaid al-Kubra al-Mausum bi Qawaid al-Ahkam fi Masalih al-Anam, Juz II. Darul Qalam, Damaskus.

Abduh, Isa. 1398 H/ 1978 M. Al-Ta'min baina al-Hill wa al-Tahrim, Cet. I. t.p, tt.p.

Fairuzabadi, Majdudin, al- 1429 H/ 2008 M. Al-Qamus al-Muhit. Darul Hadis, Kairo.

Fayumi, Ali, al-. 1987 M. Al-Misbah al-Munir. Maktabah Libnan, Libanon.

Ibnu Taimiah. 1422 H. Al-Qawaid alNuraniyah, Cet. I. Daru Ibnu al-Jauzi, Saudi Arabia.

Ibnu Manzur. t.th. Lisan al-Arab. Darul Maarif, Kairo.

Ibnu Abidin. 1423 H/ 2003 M. Radd alMukhtar ala al-Durr al-Mukhtar, Juz VII. Daru Alamil Kutub, Riyad.

Ibnu Faris. 1399 H/ 1979 M. Mu'jam Maqayis al-Lugah, Juz I. Darul Fikr, t.tp.

Ibrahim, Yasin Ahmad. t.th. Nazhariyyah alGharar fî Syariah al-Islamiyyah (Dirasah Muqaranah). t.p, t.tp.

Imraniy, Abdullah Muhammad, al-. 2010 M / 1431 H. Al-'Uqud al-Maliyyah alMurakkabah (Dirasah Fiqhiyyah Ta'shiliyyah wa Tathbiqiyyah), Cet.II. Dar al-Kunuj Isybiliya, Riyad.

Jauhari, Ismail, Al-.1990 M. Al-Sihah Taj alLugah wa Sihah al-Arabihyah, Cet. IV. 
Darul Ilmi li al-Malayin, BeirutLibanon.

Makluf, Luis. t.th. Al-Munjid fi al-Lugah, Cet. XIX. Al-Matbaah al-Kasulikiyah, Beirut.

Majma' al-Buhus al-Islamiyah. 1965. Fatawa al-Ta'min (Dikompilasikan oleh Abdul Sattar dan Izzudin Muhammad Khujah). Majma' al-Buhus alIslamiyah. Al-Azhar, Mesir.

Nawawi, Muhyidin. t.th. Al-. Al-Minhaj fi Syarh Sahih Muslim. Baitul Afkar alDaulah, t.p.

Al-Majmu Syarah alMuhazzab, Juz IX. Maktabah al-Irsyad, Jeddah.

Qal'ahji, Rawas dan Hamid Sadiq Qanibi. 1408 H/ 1988 M. Mu'jam Lugah alFuqaha. Darun Nafais, Beirut-Libanon.

Rafiq Yunus al-Mishriy. 2005 M/ 1416 H. Fiqh al-Mu'amalah al-Maliyyah, Cet.I. Darul Qalam, Damaskus.

Wazarat al-Auqaf wa al-Syuun al-Islamiah. 1414 H/ 1994 M. Al-Mausuah alFiqhiah, Juz XXXI, Cet. I. Wazarat alAuqaf wa Syuun al-Islamiah, Kuwait.

Zubaidi, Sayid Murtada, al-. 1394 H/ 1974 M. Taj al-Arus min Jawahir al-Qamus, Juz XXXIII. Wazaratul I'lam, Kuwait.

Zarqa, Mustafa Ahmad, al-. 1418 H/ 1998 M. Al-Fiqh al-Islam fi Tsaubihi al-Jadid, Cet. I. Darul Qalam, Damaskus. 